\title{
The comparison and validity and reliability study of bilateral innominate vertical length measurements using innovative digital radiographic imaging software in assessing scoliotic leg length discrepancy
}

\author{
Xiaohua He ${ }^{1 *}$, HanSuk Jung ${ }^{2}$, JooHyun Ham², KyeongAh Min²
}

From 11th International Conference on Conservative Management of Spinal Deformities - SOSORT 2014 Annual Meeting

Wiesbaden, Germany. 8-10 May 2014

\section{Background information}

The role of leg length discrepancy (LLD) has been implicated in certain types of scoliosis [1]. Scoliotic LLD has been suggested as a result of rotation of the innominate bones [2]. However, the role of innominate vertical lengths (IVLs) as a predisposing factor for scoliosis is not clear. The reliability of radiographic measurements may reveal whether IVL can be used as a factor for clinical assessment.

\section{Purpose}

Clinical investigation of quantifying bilateral IVLs and to assess the intra- and inter-observer variability using digital radiographic techniques.

\section{Methods}

Twenty $x$-ray films from scoliotic patients with LLD were chosen based on convenience, without predilection for gender and age. Images were examined by 7 trained observers to compare bilateral IVLs and to estimate the variability, as well as intra- and inter-observer variations. Each image was measured 3 times at a minimum interval of 1 week. All radiographs were calibrated by the software to allow for accurate length measurements. Student's t-test was used to compare bilateral IVLs. The intraclass correlation coefficients (ICC) were used. 95\% prediction limits for the errors in measurements to determine the interobserver and intraobserver reliabilities. A mean ICC value of 0.93 was determined for interobserver reliability and a mean ICC value of 0.96 for intraobserver reliability.

\section{Results}

Overall mean right IVL was $192.6 \pm 6.94 \mathrm{~mm}$, and left IVL was $190.4 \pm 6.95 \mathrm{~mm}$. Although there was a discrepancy between bilateral IVLs, there was no statistical significance $(\mathrm{P}>0.05)$. Interobserver ICC was 0.954 and intraobserver ICC was 0.974 .

\section{Conclusion}

Scoliosis patients with LLD might show asymmetrical IVLs; however, this discrepancy has no statistical significance; therefore, IVL is not a strong clinical indicator in assessing scoliotic LLD. On the other hand, the computer-assisted measurements are clinically advantageous and appropriate to assess scoliosis parameters. Digital measurement among different observers showed excellent reliability for the majority of IVL parameters, making it a useful method for the analysis of pathology on radiographs in scoliosis patients.

\footnotetext{
Authors' details

${ }^{1}$ Palmer College of Chiropractic Florida, Port Orange, USA. ${ }^{2} \mathrm{HanSeO}$ University, Seosan, South Korea.
} 


\section{References}

1. Raczkowski JW, Daniszewska B, Zolynski K: Functional scoliosis caused by leg length discrepancy. Arch Med Sci 2010, 6(3):393-398.

2. Friberg $\mathrm{O}$, Nurminen $\mathrm{M}$, Korhonen $\mathrm{K}$, Soininen $\mathrm{E}$, Mänttäri T: Accuracy and precision of clinical estimation of leg length inequality and lumbar scoliosis: Comparison of clinical and radiological measurements. Int Disabil Stud 1988, 10(2):49-53.

doi:10.1186/1748-7161-9-S1-09

Cite this article as: He et al:: The comparison and validity and reliability study of bilateral innominate vertical length measurements using innovative digital radiographic imaging software in assessing scoliotic leg length discrepancy. Scoliosis 2014 9(Suppl 1):09.

\section{Submit your next manuscript to BioMed Central} and take full advantage of:

- Convenient online submission

- Thorough peer review

- No space constraints or color figure charges

- Immediate publication on acceptance

- Inclusion in PubMed, CAS, Scopus and Google Scholar

- Research which is freely available for redistribution

Submit your manuscript at www.biomedcentral.com/submit
C Biomed Central 